\title{
Type-dependent differences in Fas expression and phagocytes distribution in rat corpora lutea during natural regression: an immunohistochemical evidence
}

\author{
Hironori SATOH ${ }^{1)}$, Hiromu YOSHIO ${ }^{1)}$, Mitsumori KAWAMINAMI ${ }^{1)}$ and Shiro KURUSU ${ }^{1) *}$ \\ ${ }^{1)}$ Laboratory of Veterinary Physiology, Kitasato University School of Veterinary Medicine, Towada, Aomori 034-8628, Japan
}

(Received 15 April 2016/Accepted 8 August 2016/Published online in J-STAGE 19 August 2016)

\begin{abstract}
Though Fas/Fas ligand (FasL) system-dependent apoptosis is considered to be the primary form of cell death in regressing corpus luteum (CL), the cellular identity and regulation of expression of the ligand and receptor molecules are not fully understood. Here, we focused on immunohistochemical determination of Fas expression during natural regression with comparison of three different types of rat CLs. Detected Fas was in good spatial association with cleaved caspase-3 and FasL proteins and with macrophages and neutrophils. In CLs of the cycle and pseudopregnancy, Fas-positive cell types included large and small luteal (steroidogenic) cells and capillary endothelial cells mainly, and blood-derived immune cells occasionally. Fas signals were abundant at multiple focal inflammatory-like sites. In contrast, Fas signals in CL of pregnancy did not localize in steroidogenic cells, but almost exclusively in endothelial cells and granulocytes. The signals scattered evenly throughout the CL tissue as phagocytes also did. In all CLs types, the numbers of Fas-expressing cells increased transiently after functional inactivation and at the early phase of structural regression. This observation revealed spatio-temporally regulated expression of Fas that was highly associated with apoptotic and phagocytotic systems and type-dependent differences in Fas expression and phagocytes dynamics in naturally regressing CL of rats.
\end{abstract}

KEY WORDS: corpus luteum, Fas, luteal regression, phagocytes, rat

doi: 10.1292/jvms.16-0199; J. Vet. Med. Sci. 78(12): 1771-1777, 2016

The corpus luteum (CL) is an ephemeral tissue that regresses functionally for inducing the next estrous cycle or parturition cascade and structurally for homeostasis of the organ size. The mechanism of its regression varies considerably depending on animal species, spontaneous versus induced ones, and the kinds of luteolytic factors of extra- and intra-luteal origins $[31,32]$. Death of the tissue-constituting cells, mainly steroidogenic cells and vascular endothelial cells, is a central process of CL regression. Among multiple modes of cell death, apoptosis is the typical and the most characterized one [16]. With the remarkable progress in apoptosis research, a great number of studies both in vivo and in vitro have focused on the presence of Fas receptor and ligand (FasL) system in CLs and have ascribed this signaling to the putatively common and primary pathway in cell death during structural demise [32].

The luteolytic mechanism including cell death has been most often investigated in rat and mouse models. Four types of CLs of those animals include the ones of the non-fertile cycle (CyCL), pseudopregnancy (PsCL), pregnancy (PrCL) or lactation [31]. RT-PCR and Western blot analyses demonstrated Fas expression in CL tissues/cells [5, 6, 18, 19, 28], and immunohistochemistry showed fairly ubiquitous distribution throughout the tissue of CyCL [29, 30], PsCL [5], PrCL [28] and gonadotropin-primed CyCL [4]. The level of

*Correspondence to: Kurusu, S., Laboratory of Veterinary Physiology, Kitasato University School of Veterinary Medicine, Towada, Aomori 034-8628, Japan. e-mail: kurusu@vmas.kitasato-u.ac.jp (C)2016 The Japanese Society of Veterinary Science

This is an open-access article distributed under the terms of the Creative Commons Attribution Non-Commercial No Derivatives (by-nc-nd) License $<$ http://creativecommons.org/licenses/by-nc-nd/4.0/>.
Fas expression in vivo tended to increase with age in CyCL $[29,30]$ and PrCL [5], while it was relatively constant in aging PrCL [28] and bromocryptin- and GnRH-treated PsCL [6]. Studies with cultured CL cells showed that Fas mRNA expression was increased by in vitro condition [18] and cytokines [27], unaltered by cytokines [15] or decreased by progesterone (P4) [18]. Findings from those extensive studies collectively mean that the cellular identity and CL age- and activity-related change of Fas expression are variable and not established.

Here, we specify the localization of Fas expression and the cell population that would probably undergo Fasmediated apoptosis in naturally regressing CLs of rats. By the histological/immunohistochemical approach, we identify cell types of Fas expression, test the effect of CL age on Fas-expressing cell numbers and implicate phagocytes infiltration and inflammatory-like reaction in CL regression. We also compare Fas expression and phagocytes distribution among CyCL, PsCL and PrCL, since few reports have so far addressed the common and different features in the luteolytic mechanism of various types of CLs of a given animal species [31].

\section{MATERIALS AND METHODS}

Materials: Anti-Fas antibody, its blocking peptide and 5 different kinds of antibodies were purchased commercially (Supplementary Table 1). Vectastain Elite ABC staining kit was obtained from Vector Laboratories (Burlingame, CA, U.S.A.). All other reagents were of analytical grade.

Animals and tissue sampling: Animal handling and experimental procedures were approved by the Committee for Laboratory Animals Care and Use at Kitasato University 
School of Veterinary Medicine (Approval number, 12-006). Female rats of Wistar-Imamichi strain that were 3 4 months old, 250 350 g in weight and showing a regular 4-day estrous cycle were used. Pseudopregnancy was induced by mechanical stimuli of vagina, and the first day of the diestrous smear was designated as day 1 of pseudopregnancy (PSP1). Pregnancy was induced by mating with a fertile male, and the day of fertilization (the estrous smear with sperm) was designated as day 1 of pregnancy (PRG1). The duration of pregnancy was 23 days, and therefore, PRG23 corresponded to day 0 of postpartum (PP0).

During 09:00 11:00 hr of the day, animals were sacrificed by cervical dislocation under anesthesia, and ovaries were harvested. The ovaries of cycling rats were harvested on the estrus, based on the finding that PRL surge occurring in the proestrous afternoon is a potential inducer of apoptotic changes and macrophage infiltration in CyCLs [9, 22]. Pseudopregnant animals were sacrificed on PSP6 (active luteal phase), PSP12 (functionally regressed phase) and PSP15. Pregnant rats were sacrificed on PRG6, PRG15, PRG19, PRG21 and PRG23 (just before delivery or just delivering). Postpartum rats were done on PP0 (just after delivery), PP3 and PP6.

Immunohistochemsitry: Expression of Fas, FasL, cleaved caspase-3 (active form), myeloperoxidase (MPO, a neutrophil marker) or CD68 (a monocyte/macrophage marker) in the CLs was analyzed by immunohistochemistry. Ovaries were fixed in Bouin's solution, dehydrated and embedded in paraffin. Samples from more than 3 individual rats in each group were examined. Tissues were serially sectioned (3 $5 \mu \mathrm{m}$ in thickness), deparaffinized and examined. Endogenous peroxidase activity was quenched by pretreatment with $0.3 \% \mathrm{H}_{2} \mathrm{O}_{2}$ in methanol for $30 \mathrm{~min}$. All the following procedures used $0.01 \mathrm{M}$ phosphate buffered saline (PBS) $\mathrm{pH}$ 7.5 as the standard aqueous buffer for Fas, MPO and CD68 staining. For staining of FasL and cleaved caspase-3, $0.01 \mathrm{M}$ Tris buffered saline (TBS) pH 7.5 was used instead, and for retrieval of these two antigens, tissue sections were treated with microwave in $10 \mathrm{mM}$ citrate buffer for $10 \mathrm{~min}$ followed by treatment with $0.1 \mathrm{mM}$ glycine in TBS for $30 \mathrm{~min}$. Tissue sections were incubated with each specific antibody, whose dilution at use was described in Supplementary Table 1, at $4^{\circ} \mathrm{C}$ overnight. Antigen/antibody complexes were visualized with the Vectastain $\mathrm{ABC}$ staining kit and 3,3'-diaminobenzidine tetrahydrochrolide as peroxidase substrate. Negative controls were performed with non-immunized mouse IgG. To confirm the specificity of the anti-Fas antibody against Fas especially, an equal volume of the antibody with Fas/ Apo1 blocking peptide solution $(0.5 \mathrm{mg} / \mathrm{m} l)$ was incubated at $4^{\circ} \mathrm{C}$ for $3 \mathrm{hr}$ just before use. All slides were counterstained with hematoxylin.

As signals of Fas immunoreaction were not always present evenly throughout the tissue but often localized densely to several focal sites, the number of all signals was counted throughout cross-sectioned area of each CL and was divided by the area $\left(\mathrm{mm}^{2}\right)$. Much care was taken for CyCLs examination to differentiate into four stages (generations) based on their histological features $[21,30]$ and to exclude the newest CLs that just began to be formed in the morning of the harvest day. As for PsCLs and PrCLs, putative tissues were selected based on the histological feature and evaluated. Five to 9 different ovarian specimens of each group were investigated, and the numbers of CL evaluated were indicated in figure legends.

Statistical analysis: All numerical data were presented as mean \pm SEM. Differences of the means among groups were analyzed by Tukey-Kramer's multiple comparison test. $P<0.05$ was considered significant.

\section{RESULTS}

Immunohistochemical localization of Fas in CyCLs of the estrous rat: Fas immunostaining was first validated in the ovary harvested in the estrous morning. In many CyCLs, Fas immunoreactions were evidently and densely detected at multiple focal sites with tissue damage and accumulation of inflammatory cells (Fig. 1A, 1E and 1G). The reaction was less frequently, but evidently scattered in the remaining, seemingly intact sites. These signals were clearly abolished by antibody pre-absorption (Fig. 1B). The positive cell types in CyCLs included large and small steroidogenic cells, capillary endothelial cells and leukocytes (granulocytes and macrophages), many of which lost the integrity of plasma and nuclear membranes (Fig. 1C).

Adjacent sections of CyCLs were used to investigate whether the detected Fas signals associated or not spatially with FasL and cleaved caspase-3 localization. The immunoreactions of FasL (Fig. 1D) were closely associated with the presence of Fas (Fig. 1E) at focal sites, probably along the distribution of intra-luteal blood capillaries. FasL immunoreactions were present in blood-derived, non-luteal cells and steroidogenic cells (Supplementary Fig. 1A). Intra-tissue distribution of immunoreactive cleaved caspase- 3 overlapped in large part with that of Fas, with their dominant presence at focal inflammatory-like sites (Fig. 1F). Large magnification revealed the cell types possessing the executor caspase as steroidogenic cells, capillary endothelial cells and granulocytes (Supplementary Fig. 1B). Slighter immunoreactions distributed broadly in remaining luteal cells. The spatial association of a set of FasL/Fas/cleaved caspase-3 was also evident in granulosa cells of an atretic follicle present in the same ovarian specimen (data not shown).

A previous finding that neutrophils and monocytes/macrophages were the most abundant leukocytes in rat CLs [3] led us next to determine their distribution in relation with that of Fas signal. The focal sites with densely scattered immunoreactions of Fas (Fig. 1G) also exhibited accumulated signals of MPO-positive cells (Fig. 1H and Supplementary Fig. 2A) and CD68-positive cells (Fig. 1I and Supplementary Fig. 2B). In addition to disappearance of signals after antibody neutralization, these associations of apoptotic and phagocytotic systems increase the validity of the current immunological detection of Fas and cells that would undergo Fas-mediated cell death and their engulfment.

Fas immunolocalization in regressing PSCL and PrCL: Next, we determined Fas expression in regressing PsCL 


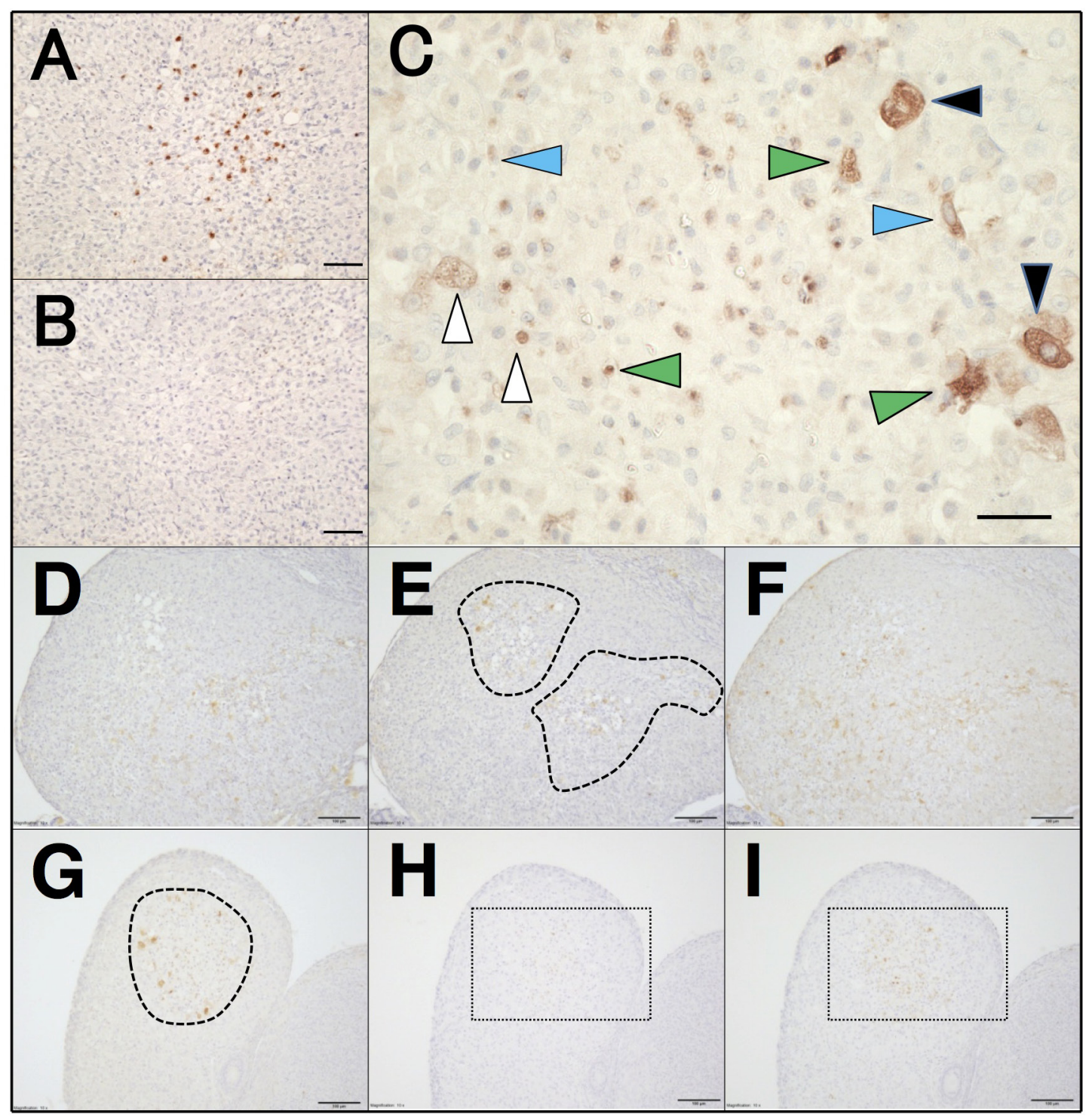

Fig. 1. Immunolocalization of Fas and related factors in CyCL of the estrous rat. (A) Fas immunostaining in CyCL. (B) Pre-absorption of the antibody with the blocking peptide completely abolished the immunoreaction. (C) Immunoreactive Fas-positive cell types include large (black arrowheads) and small (white arrowheads) luteal cells, capillary endothelial cells (blue arrowheads) and blood derived granulocytes and macrophages (green arrowheads). Positive immunoreactions for FasL (D), Fas (E) and cleaved caspase-3 (F), the most of which were densely scattered in inflammatory-like and fibrotic sites (closed dashed lines in E) in the CyCL. Larger magnification of portions of central zone of D and F was available in Supplementary Fig. 1A and 1B, respectively, to identify the immunopositive cell types. Associated immunostaining for Fas $(\mathrm{G})$, MPO (H) and CD68 (I) was also abundant to inflammatory-like and fibrotic sites (surrounded by the dashed line in G). Magnification of rectangles with dashed lines in $\mathrm{H}$ and I was available in Supplementary Fig. 2A and 2B, respectively. Scale bars, $50 \mu \mathrm{m}$ (A, B), $25 \mu \mathrm{m}(\mathrm{C}), 100 \mu \mathrm{m}(\mathrm{D}-\mathrm{I})$.

and PrCL that had once been functionally activated. In the ovary harvested on PSP15, Fas signals were accumulated to the focal, inflammatory-like regions of degenerating PsCL (Fig. 2A), similarly to that in CyCL. The immunoreactive cell types were mostly steroidogenic cells with irregular shapes of nuclear structures, almost identical to that in $\mathrm{Cy}-$ CLs (Fig. 2B).
In contrast to CyCLs and PsCLs, PrCLs harvested on PP0 did not involve focal inflammatory-like reactions. The absence was also the case at other time points of regression examined. Fas-positive signals (Fig. 2C and Supplementary Fig. 3A) were scattered throughout the tissue and MPO-positive neutrophils (Fig. 2D and Supplementary Fig. 3B) and CD68positive macrophages (Fig. 2E and Supplementary Fig. 3C) 


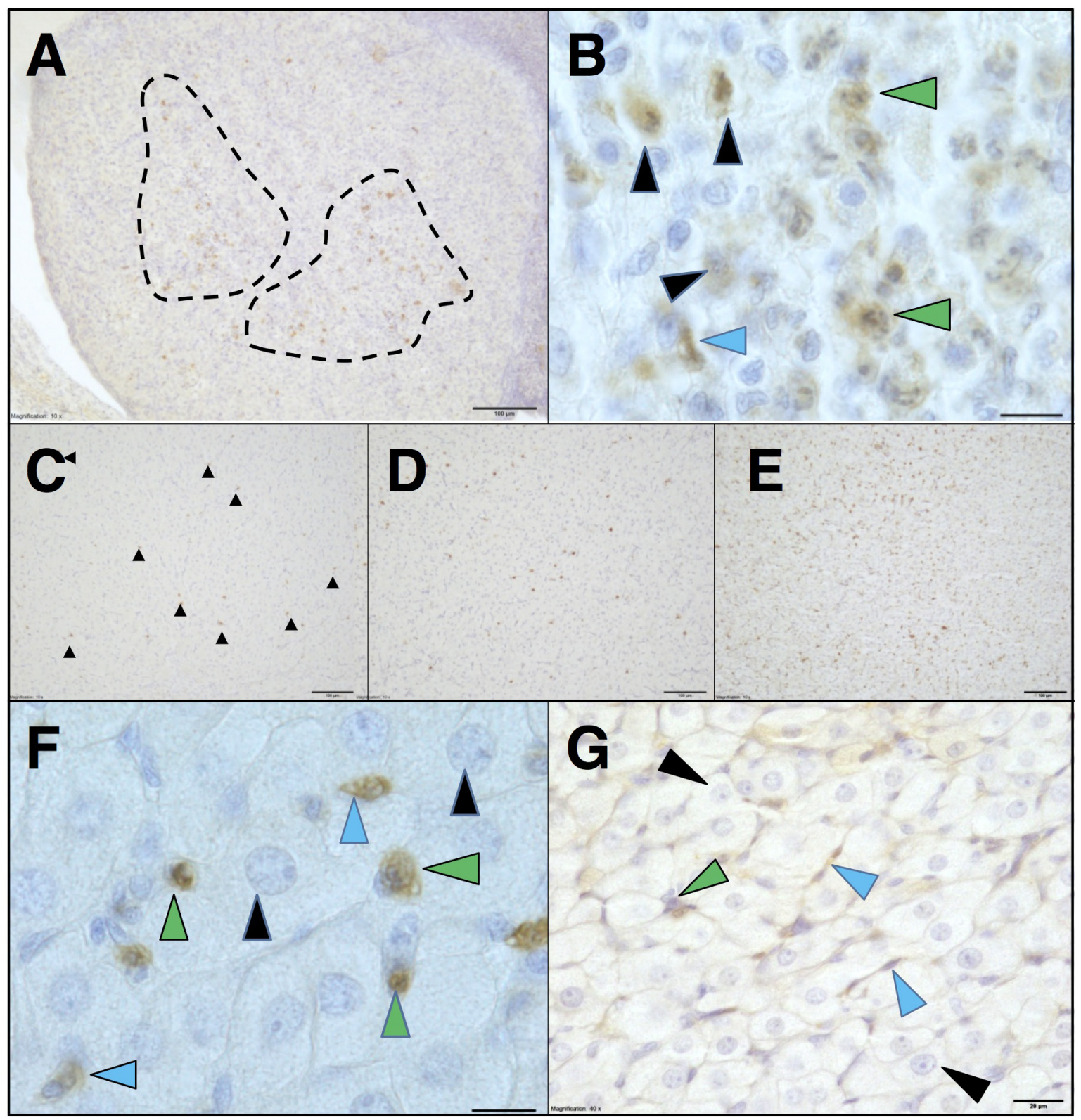

Fig. 2. Fas and associated phagocytes distribution in PsCL and PrCL. Immunoreactive Fas signals on PSP15 located frequently at focal sites of inflammatory-like reactions (marked by the dashed lines) in regressed PsCL (A). The signals were present on steroidogenic cells (black arrowhead), endothelial cells (blue arrowhead) and granulocytes (green arrowheads) (B). Fas signals (highlighted with black arrowheads) (C) as well as MPO-positive cells (D) and CD68-positive cells (E) were fairly evenly scattered throughout the PrCL tissue sampled on PP0. Fas signals were present on endothelial cells (blue arrowhead) and migratory cells (green arrowheads), but not steroidogenic cells with intact nuclear structure (black arrowheads) (F). Signals of cleaved caspase-3 in a portion of PrCL were predominant in endothelial cells (blue arrowheads) and absent in steroidogenic cells (black arrowheads) $(\mathrm{G})$. Scale bars, $100 \mu \mathrm{m}$ (A, C, D, E), $12.5 \mu \mathrm{m}$ (B, F), $20 \mu \mathrm{m}(\mathrm{G})$.

also distributed fairly evenly throughout the tissues. Fas signals existed exclusively in endothelial cells and immune cells (Fig. 2F). Hypertrophied steroidogenic cells with intact nuclei structure were negative for Fas. The immunoreactions for cleaved caspase- 3 in PrCLs were dominant in endothelial cells, positive but to a lesser extent in leukocytes, and very faint in steroidogenic cells (Fig. 2G).

Age-related dynamics of the number of Fas-positive cells in CLs: Fas expression was morphometrically evaluated by counting the numbers of Fas-positive cells in three types of CLs under different functional and structural states (Table 1).

In CyCLs, multiple focal sites with inflammatory-like and 
Table 1. Age-related changes in the number of Fas-positive cells in 3 types of CL

\begin{tabular}{|c|c|c|c|c|c|c|c|}
\hline \multirow{2}{*}{ Stage 1} & \multicolumn{2}{|l|}{ CyCL } & \multicolumn{2}{|r|}{ PsCL } & \multicolumn{3}{|r|}{ PrCL } \\
\hline & $9.3+/-2.1^{\text {a) }}(18)$ & PSP & 6 & $6.0+/-3.4^{\mathrm{a})}(11)$ & PRG & 6 & $7.7+/-1.9^{\mathrm{a}, \mathrm{b})}(17)$ \\
\hline 2 & $26.9+/-3.9^{\text {b) }}(34)$ & & 12 & $28.1+/-7.1^{\text {b) }}(20)$ & & 15 & $17.3+/-3.4^{\text {b) }}(9)$ \\
\hline 3 & $10.1+/-2.7^{\text {a) }}(17)$ & & 15 & $15.8+/-4.6^{\mathrm{a}, \mathrm{b})}(23)$ & & 19 & $3.3+/-1.0^{\mathrm{a})}(16)$ \\
\hline 4 & $10.0+/-2.7^{\text {a) }}(30)$ & & & & & 21 & $6.4+/-2.7^{\mathrm{a}, \mathrm{b})}(17)$ \\
\hline & & & & & & 23 & $28.3+/-4.7^{\mathrm{c})}(17)$ \\
\hline & & & & & PP & 3 & $23.4+/-4.1^{b, c)}(27)$ \\
\hline & & & & & & 6 & $2.8+/-1.3^{\text {a) }}(9)$ \\
\hline
\end{tabular}

Fas antigen was counted in distinct ages of CyCL, PsCL and PrCL and displayed as the number (mean $+/-$ SEM) of positive cells per defined area $\left(/ \mathrm{mm}^{2}\right)$ of CL sections. The number in parentheses showed each number of CLs examined that were obtained from 5-9 ovarian specimens. Different alphabetical letters in the superscript within the same row mean significant differences among the stages of each CLs $(P<0.05)$.

degenerative reactions were evident in the stage 2 of CLs, where Fas expression was marked (Fig. 1A, 1E and 1G). The number of Fas-positive cells in the newest CLs (stage 1) was $9.3 \pm 2.1 / \mathrm{mm}^{2}$, and it showed a 2.9 fold-increase $(P<0.05)$ in the stage 2 . The number decreased in the stage 3 as the inflammatory-like reaction turned to resolution. It remained low in the last stage as the resolution of inflammation-like reaction and fibrotic replacement were almost completed. This stage-related change in Fas expression is similar to those of inflammation-associated infiltration of neutrophils and macrophages described in our previous report [21].

In PsCLs, the number of Fas-positive cells increased from $6.0 \pm 3.4 / \mathrm{mm}^{2}$ on PSP6 to $28.1 \pm 7.1$ on PSP12 $(P<0.05)$ (Table 1). The value decreased on PSP15 to the level insignificantly different from both of those on PSP6 and PSP12.

In PrCLs, the number of Fas expressing cells was $7.7 \pm$ $1.9 / \mathrm{mm}^{2}$ on PRG6 and increased significantly on PRG15 (Table 1) when P4 secretory function was further potentiated. The value once declined to the basal level on PRG19 and PRG21 and increased drastically on PP0 (a 4.4 foldincrease from PRG21, $P<0.05)$. It remained elevated on PP3 and decreased to the basal level on PP6 $(P<0.01)$.

\section{DISCUSSION}

We here have specified and localized the cells expressing immunoreactive Fas in naturally regressing CLs of rats. Histological evidence supports the good spatial association of those Fas-positive cells with apoptotic (FasL and active casapse-3) and phagocytotic (macrophages and neutrophils) machineries. The comparative study has revealed that PrCL shows the unique features in steroidogenic cell Fas expression and occurrence of inflammatory-like reaction, both of which are different from those in CyCL and PsCL.

Several reports on Fas immunohistochemistry of rat and mouse ovaries have been so far available, but all of those prepared the negative control groups by replacement with non-specific antibody or the omission of the primary antibody. The currently prepared negative control (the antibody neutralization) is the most appropriate one, warranting the more reliability of Fas detection. Rat CL cells possessing Fas immunoreactivity in vivo include steroidogenic cells and vascular endothelial cells mainly, and granulocytes additionally [2]. In the term of the cell types, our data are largely consistent with previous reports on Fas immunohistochemistry of rat and mouse CyCLs [15, 29, 30]. Intra-tissue distribution and aging-related changes of Fas expression are, however, distinct from those in previous reports. Frequent and focal occurrence of Fas-expressing cells at multiple sites and the temporal increase in Fas-positive cells' number are common characteristics in CyCLs and PsCLs. This feature of spatial distribution of Fas is well consistent with and strongly supported by morphologic assessment of apoptosis in naturally regressing CyCLs [14, 15, 17] and PsCLs [12, 13] using the terminal deoxynucleotidyl transferase nick end labeling (TUNEL) method.

One important finding of this study is the probable lack of Fas expression specifically in steroidogenic cells of PrCLs. This might coincide with the previously reported $[5,25]$ and currently confirmed fact that the effecter caspase- 3 was present in steroidogenic cells at the lesser amount than that in endothelial cells. Furthermore, not a few studies in vivo have presented evidence for vague or modest apoptotic signs of DNA fragmentation in steroidogenic cells of peri-parturient PrCLs $[5,11,20,25,33]$. Evidence in vitro that rat PrCL isolated before and after parturition represented DNA fragmentation following serum deprivation $[1,11]$ does not mean its actual occurrence in vivo. Taken with the consideration of evident Fas expression in steroidogenic cells in CyCL and PsCL, an unknown mechanism associated with further activation of PrCL in the second half of pregnancy [31] may protect steroidogenic cells specifically from Fas expression. Action of sole P4 is unlikely responsible, because steroidogenic cells expression of Fas occurred in PsCL. Previous studies have shown enhanced expression and activity of caspase- 3 and its up-stream caspases-2, -8 and -9 in rat PrCL tissue at term $[25,33]$. It may be possible that a non-Fas death signal, tumor necrosis factor (TNF) $\alpha$ shown to be expressed in steroidogenic cells in PrCL [1] causes caspase-3 activation, but not reaching to DNA degradation in vivo. We found marked presence of cytoplasmic vacuole and seemingly intact nuclei in steroidogenic cells of PrCL previously [20] and here again. PrCL regression is likely to involve celltype-dependent different modes of cell death. 
Spatio-temporally matched appearance of Fas-positive cells in regressing CLs strongly suggests Fas expression as a critical regulatory component of regression. Previous reports with a variety of CLs models [5, 6, 15, 17, 28] demonstrated that FasL, rather than Fas, was more actively regulated and thus was more responsible for FasL/Fasmediated apoptotic signaling during regression. However, our quantitative data of Fas expression correlated temporally with TUNEL-sensitive apoptosis in CyCL $[9,22]$ and PrCL $[11,20,25,33]$, suggesting an active role of Fas. This study does not identify what regulates Fas expression in regressing CL. P4 suppressed Fas mRNA expression in steroidogenic cells from rat [19] and bovine [23] CLs in vitro. In vivo this steroid inhibited apoptosis induction in postpartum rat PrCL $[10,11]$, but facilitated PRL-induced apoptosis in rat CyCL $[8,26]$. In our experiments of modulation of $\mathrm{P} 4$ synthesis or action by local administration of P4, RU486 or trilostane in vivo, there were no alterations in Fas expression in CyCL, PsCL and PrCL (data not shown). The discrepancies between in vivo and in vitro studies and among different CLs models suggest the complex mechanism elaborated through the synthesis and action (sensitivity) of P4. They may also be related partly to the differential indices of determining Fas expression between previous studies [19, 23] (RT-PCR analysis on purified steroidogenic cells) and ours (morphometric counting of all cell types positive for Fas).

Distribution of FasL was similar to that of Fas in regressing CyCLs, but the cell types expressing FasL are not sufficiently solved in this study. Kuranaga et al. [17, 18] documented CD3-positive T lymphocytes as an effecter of PRL-stimulated FasL expression and its induction of Fasmediated apoptosis of steroidogenic cells in a rat $\mathrm{CyCL}$ model. Previous studies with other types of rat CLs [5, 28, 30] and this study (Supplementary Fig. 1A), however, strongly suggest that FasL-expressing cells are not such lymphocytes exclusively. To clarify the source, expressional regulation and functional interaction with Fas of FasL are essential to further understand Fas-mediated cell death occurring in regressing CL.

Similar distribution of accumulated neutrophils/macrophages and Fas expression in any types of regressing CLs is significant. These data support the general concept that phagocytes are actively recruited into impaired region(s) of regressing CLs and contribute to tissue destroy and remodeling through secreting cytotoxic TNF $\alpha$ and interferon $\gamma$, killing and engulfing cells and debris, and secreting extracellular matrix proteases $[14,15,24]$. Accumulation of phagocytes at multiple foci in CyCL and PsCL represents a typical inflammatory-like feature, whereas their distribution evenly throughout PrCL tissue does a distinct ("non-focal" and "mild") inflammatory feature. This is, as far as we know, the first indication of the spatial nature of Fas expression and immune cells distribution in regressing CL and of CL type-dependent difference. Furthermore, the occurrence of Fas-positive cell in PrCL is also similar to the temporal alteration in infiltrated neutrophils and macrophages (our unpublished data), suggesting a shared local regulation of Fas expression and phagocytes mobilization. Our effort is now made to study some unique features exhibited by rat PrCL in the latter half of pregnancy and postpartum.

In summary, this study reveals a part of the nature of Fas expression in rat CL. Findings on Fas expression by multiple cell types in a spatio-temporally regulated manner provide further insight into the luteolytic mechanism involving Fasrelated cell death and phagocytes-associated inflammatorylike response. Their differences among the CL types within a species make us recognize again the diverse regulatory mechanism of mammalian CL. In many experimental models as well as CLs, different methods of apoptosis detection and data evaluation have produced so variable results and conclusions [16]. The cell death mechanism during CL regression should be searched further and again with the aid of more advanced knowledge and methodology on apoptosis and other modes of cell death $[7,16]$.

ACKNOWLEDGMENTS. The authors thank S. Haruta and S. Nagashima for experimental help, T. Yonezawa and M. Sugiyama for critical discussions and M. Nakata for help in the manuscript preparation. This study was supported by Japan Society for the Promotion of Science, KAKENHI16K0876.

\section{REFERENCES}

1. Abdo, M., Hisheh, S. and Dharmarajan, A. 2003. Role of tumor necrosis factor- $\alpha$ and the modulating effect of the caspases in rat corpus luteum apoptosis. Biol. Reprod. 68: 1241-1248. [Medline] [CrossRef]

2. Akgul, C. and Edwards, S. W. 2003. Regulation of neutrophil apoptosis via death receptors. Cell. Mol. Life Sci. 60: 2402-2408. [Medline] [CrossRef]

3. Brännström, M., Giesecke, L., Moore, I. C., van den Heuvel, C. J. and Robertson, S. A. 1994. Leukocyte subpopulations in the rat corpus luteum during pregnancy and pseudopregnancy. Biol. Reprod. 50: 1161-1167. [Medline] [CrossRef]

4. Carambula, S. F., Pru, J. K., Lynch, M. P., Matikainen, T., Gonçalves, P. B. D., Flavell, R. A., Tilly, J. L. and Rueda, B. R. 2003. Prostaglandin $F_{2} \alpha$ - and FAS-activating antibody-induced regression of the corpus luteum involves caspase- 8 and is defective in caspase-3 deficient mice. Reprod. Biol. Endocrinol. 1: 15. [Medline] [CrossRef]

5. Chen, X., Gao, H., Wei, P., Zhang, Z. and Liu, Y. 2003. Expression of apoptosis-related genes Fas/FasL, Bax/Bcl-2 and Caspase-3 in rat corpus luteum during luteal regression. Sci. China C Life Sci. 46: 273-285. [Medline]

6. Endo, T., Kiya, T., Kitajima, Y., Honnma, H., Chida, M., Hayashi, T., Henmi, H., Yamazaki, K., Hayashi, T., Manase, K. and Kudo, R. 2005. Identical changes in Bax expression, but not Fas ligand expression, occur in structural luteolysis in gonadotropin releasing hormone agonist- and prolactin-treated superovulated rats. Life Sci. 76: 2159-2169. [Medline] [CrossRef]

7. Galluzzi, L., Vitale, I., Abrams, J. M., Alnemri, E. S., Baehrecke, E. H., Blagosklonny, M. V., Dawson, T. M., Dawson, V. L., ElDeiry, W. S., Fulda, S., Gottlieb, E., Green, D. R., Hengartner, M. O., Kepp, O., Knight, R. A., Kumar, S., Lipton, S. A., Lu, X., Madeo, F., Malorni, W., Mehlen, P., Nuñez, G., Peter, M. E., Piacentini, M., Rubinsztein, D. C., Shi, Y., Simon, H. U., Vandenabeele, P., White, E., Yuan, J., Zhivotovsky, B., Melino, G. and Kroemer, G. 2012. Molecular definitions of cell death 
subroutines: recommendations of the Nomenclature Committee on Cell Death 2012. Cell Death Differ. 19: 107-120. [Medline] [CrossRef]

8. Gaytán, F., Bellido, C., Morales, C. and Sánchez-Criado, J. E. 1998. Both prolactin and progesterone in proestrus are necessary for the induction of apoptosis in the regressing corpus luteum of the rat. Biol. Reprod. 59: 1200-1206. [Medline] [CrossRef]

9. Gaytán, F., Bellido, C., Morales, C. and Sánchez-Criado, J. E. 2001. Luteolytic effect of prolactin is dependent on the degree of differentiation of luteal cells in the rat. Biol. Reprod. 65: 433-441. [Medline] [CrossRef]

10. Goyeneche, A. A., Deis, R. P., Gibori, G. and Telleria, C. M. 2003. Progesterone promotes survival of the rat corpus luteum in the absence of cognate receptors. Biol. Reprod. 68: 151-158. [Medline] [CrossRef]

11. Goyeneche, A. A., Martinez, I. L., Deis, R. P., Gibori, G. and Telleria, C. M. 2003. In vivo hormonal environment leads to differential susceptibility of the corpus luteum to apoptosis in vitro. Biol. Reprod. 68: 2322-2330. [Medline] [CrossRef]

12. Hasumoto, K., Sugimoto, Y., Yamasaki, A., Morimoto, K., Kakizuka, A., Negishi, M. and Ichikawa, A. 1997. Association of expression of mRNA encoding the $\mathrm{PGF}_{2} \alpha$ receptor with luteal cell apoptosis in ovaries of pseudopregnant mice. J. Reprod. Fertil. 109: 45-51. [Medline] [CrossRef]

13. Kawaminami, M., Shibata, Y., Yaji, A., Kurusu, S. and Hashimoto, I. 2003. Prolactin inhibits annexin 5 expression and apoptosis in the corpus luteum of pseudopregnant rats: involvement of local gonadotropin-releasing hormone. Endocrinology 144 : 3625-3631. [Medline] [CrossRef]

14. Komatsu, K., Manabe, N., Kiso, M., Shimabe, M. and Miyamoto, H. 2003. Changes in localization of immune cells and cytokines in corpora lutea during luteolysis in murine ovaries. J. Exp. Zoolog. A Comp. Exp. Biol. 296: 152-159. [Medline] [CrossRef]

15. Komatsu, K., Manabe, N., Kiso, M., Shimabe, M. and Miyamoto, H. 2003. Soluble Fas (FasB) regulates luteal cell apoptosis during luteolysis in murine ovaries. Mol. Reprod. Dev. 65 : 345-352. [Medline] [CrossRef]

16. Kroemer, G., Galluzzi, L., Vandenabeele, P., Abrams, J., Alnemri, E. S., Baehrecke, E. H., Blagosklonny, M. V., El-Deiry, W. S., Golstein, P., Green, D. R., Hengartner, M., Knight, R. A., Kumar, S., Lipton, S. A., Malorni, W., Nuñez, G., Peter, M. E., Tschopp, J., Yuan, J., Piacentini, M., Zhivotovsky, B., Melino G., Nomenclature Committee on Cell Death 2009 2009. Classification of cell death: recommendations of the Nomenclature Committee on Cell Death 2009. Cell Death Differ. 16: 3-11. [Medline] [CrossRef]

17. Kuranaga, E., Kanuka, H., Bannai, M., Suzuki, M., Nishihara, M. and Takahashi, M. 1999. Fas/Fas ligand system in prolactininduced apoptosis in rat corpus luteum: possible role of luteal immune cells. Biochem. Biophys. Res. Commun. 260: 167-173. [Medline] [CrossRef]

18. Kuranaga, E., Kanuka, H., Furuhata, Y., Yonezawa, T., Suzuki, M., Nishihara, M. and Takahashi, M. 2000. Requirement of the Fas ligand-expressing luteal immune cells for regression of corpus luteum. FEBS Lett. 472: 137-142. [Medline] [CrossRef]

19. Kuranaga, E., Kanuka, H., Hirabayashi, K., Suzuki, M., Nishihara, M. and Takahashi, M. 2000. Progesterone is a cell death suppressor that downregulates Fas expression in rat corpus luteum. FEBS Lett. 466: 279-282. [Medline] [CrossRef]
20. Kurusu, S., Suzuki, K., Taniguchi, K., Yonezawa, T. and Kawaminami, M. 2009. Structural regression of the rat corpus luteum of pregnancy: relationship with functional regression, apoptotic cell death, and the suckling stimulus. Zoolog. Sci. 26: 729-734. [Medline] [CrossRef]

21. Masuda, K., Haruta, S., Orino, K., Kawaminami, M. and Kurusu, S. 2013. Autotaxin as a novel, tissue-remodeling-related factor in regressing corpora lutea of cycling rats. FEBS J. 280: 6600-6612. [Medline] [CrossRef]

22. Nagaosa, K., Shiratsuchi, A. and Nakanishi, Y. 2002. Determination of cell type specificity and estrous cycle dependency of monocyte chemoattractant protein-1 expression in corpora lutea of normally cycling rats in relation to apoptosis and monocyte/ macrophage accumulation. Biol. Reprod. 67: 1502-1508. [Medline] [CrossRef]

23. Okuda, K., Korzekwa, A., Shibaya, M., Murakami, S., Nishimura, R., Tsubouchi, M., Woclawek-Potocka, I. and Skarzynski, D. J. 2004. Progesterone is a suppressor of apoptosis in bovine luteal cells. Biol. Reprod. 71: 2065-2071. [Medline] [CrossRef]

24. Pate, J. L. and Landis Keyes, P. 2001. Immune cells in the corpus luteum: friends or foes? Reproduction 122: 665-676. [Medline] [CrossRef]

25. Peluffo, M. C., Stouffer, R. L. and Tesone, M. 2007. Activity and expression of different members of the caspase family in the rat corpus luteum during pregnancy and postpartum. Am. J. Physiol. Endocrinol. Metab. 293: E1215-E1223. [Medline] [CrossRef]

26. Port, C. B., Bowen, J. M., Keyes, P. L. and Townson, D. H. 2000. Effects of a $3 \beta$-hydroxysteroid dehydrogenase inhibitor on monocyte-macrophage infiltration into rat corpus luteum and on apoptosis: relationship to the luteolytic action of prolactin. $J$. Reprod. Fertil. 119: 93-99. [Medline] [CrossRef]

27. Quirk, S. M., Harman, R. M., Huber, S. C. and Cowan, R. G. 2000. Responsiveness of mouse corpora luteal cells to Fas antigen (CD95)-mediated apoptosis. Biol. Reprod. 63: 49-56. [Medline] [CrossRef]

28. Roughton, S. A., Lareu, R. R., Bittles, A. H. and Dharmarajan, A. M. 1999. Fas and Fas ligand messenger ribonucleic acid and protein expression in the rat corpus luteum during apoptosismediated luteolysis. Biol. Reprod. 60: 797-804. [Medline] [CrossRef]

29. Sakamaki, K., Yoshida, H., Nishimura, Y., Nishikawa, S., Manabe, N. and Yonehara, S. 1997. Involvement of Fas antigen in ovarian follicular atresia and luteolysis. Mol. Reprod. Dev. 47: 11-18. [Medline] [CrossRef]

30. Slot, K. A., Voorendt, M., de Boer-Brouwer, M., van Vugt, H. H. and Teerds, K. J. 2006. Estrous cycle dependent changes in expression and distribution of Fas, Fas ligand, Bcl-2, Bax, and pro- and active caspase-3 in the rat ovary. J. Endocrinol. 188: 179-192. [Medline] [CrossRef]

31. Stocco, C., Telleria, C. and Gibori, G. 2007. The molecular control of corpus luteum formation, function, and regression. Endocr. Rev. 28: 117-149. [Medline] [CrossRef]

32. Sugino, N. and Okuda, K. 2007. Species-related differences in the mechanism of apoptosis during structural luteolysis. J. Reprod. Dev. 53: 977-986. [Medline] [CrossRef]

33. Takiguchi, S., Sugino, N., Esato, K., Karube-Harada, A., Sakata, A., Nakamura, Y., Ishikawa, H. and Kato, H. 2004. Differential regulation of apoptosis in the corpus luteum of pregnancy and newly formed corpus luteum after parturition in rats. Biol. Reprod. 70: 313-318. [Medline] [CrossRef] 